\title{
James March as an Academic Don Quixote: My Personal Memory
}

\section{Dear Editor-in-Chief,}

I was hugely shocked and greatly saddened by the news about the passing of James March on September 28, 2018 (China time). First, I was totally surprised because I just met James March (hereafter I refer to him as 'Jim' as he always wanted others to call him) and had a conversation with Jim on the afternoon of August 31, 2018. Jim looked fragile and could not walk, and even had a hard time standing up on his own. However, Jim appeared sharp as always when we started our engaging conversation. Hence, I never expected Jim could leave us within less than a month. Second, I felt so sad about the passing of Jim because this was a deep loss for me as an informal mentee with Jim as my informal mentor over the past eight years. As implied by the Chinese notion of 'shifu' (师父 in Chinese) as the Chinese version of mentor, I emotionally saw Jim as father figure. Jim was about my father's age (Jim was one year younger than my father who is over 91 and still healthy).

I came to know about Jim as a great scholar and his accomplished research mostly from his 1991 article in Organization Science and his 1993 article in Strategic Management Fournal concerning the complex link between exploration and exploitation. I loved his ideas and cited his articles in my own early publications. Later, I read his article in the inaugural issue of Management and Organization Review (MOR) in 2005 and equally loved it, so I also cited it a lot in my later publications. Finally, Jim's articles about ambiguity, foolishness, and playfulness were cited in my more recent research on the Chinese cognitive methodology of 'wu' (悟 in Chinese) in terms of intuitive imagination for insight via metaphor.

There is no doubt that the above articles by Jim heavily shaped my research on organizational learning, innovation, structure, and strategy, especially from the indigenous Chinese perspective.

When I joined Copenhagen Business School (CBS) at the start of 2010, I learned more about Jim as a person above and beyond his status as one of the best-known scholars. This was because of his affiliation with CBS as an honorary professor. Jim loved CBS and also the Scandinavian region in general. One day in the second semester at CBS, I had a crazy idea of contacting him directly, so I sent an email message to Jim, with little hope that he would reply. To my biggest 
surprise and also my biggest happiness, he replied quickly in a positive manner. He welcomed me to visit him at Stanford if I came back to my home in Northern California.

My first meeting with Jim was on December 13, 2010 (see the photo), and after that I normally visited him twice or more per year, often during breaks from my Spring and Fall semesters when I came back from Denmark (from 2010-2015) and from China (from 2015-2018).

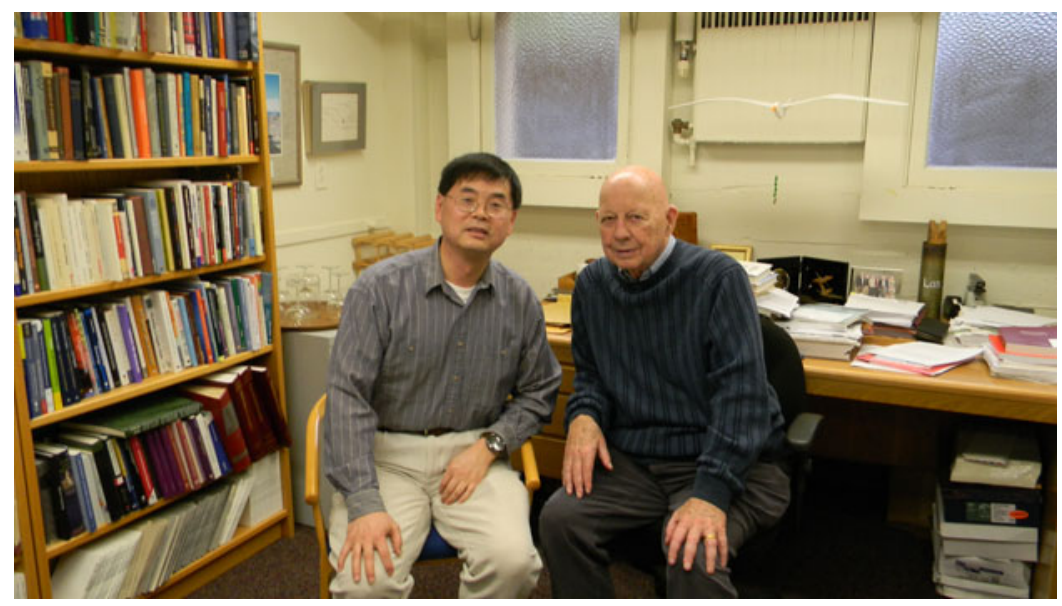

Jim March

In 2012, my co-authors and I finished an article about our explanation of the paradoxical link between exploration and exploitation, also widely known as ambidexterity. We proposed and tested our argument that exploration and exploitation are jointly responsible for both radical and incremental innovations with their different configurations or balances in the inverted U-shaped patterns.

During my several visits with Jim, I kept asking for his comments about our approach in the paper. Despite his strong interest in the perspective of yin-yang balancing, Jim would not give me an unequivocal answer except for general encouragement for me to push ahead. Jim often told me that we were on the right track, but we still had a long way to go.

I learned that Jim was unhappy about research on ambidexterity. He argued that the current versions of ambidextrous research ignore the root tension in terms of intensive competition between exploration and exploitation for required resources as a fundamental tradeoff. The core issue of resource competition had NOT been adequately addressed by any of the schools of ambidexterity research. I found myself agreeing with Jim on this point.

When he learned more about the Chinese cognitive frame of yin-yang balancing, where paradoxes would be reframed as duality for both conflicting tradeoff and complementary synergy between opposite elements, Jim gradually embraced it above and beyond a simple curiosity or general interest. He once told me that my 
research on the exploration-exploitation link from the perspective of yin-yang balancing was so far the closest to his own view.

Over the years, he clearly showed his growing interest in Chinese traditional philosophy. In addition to his growing embracement of yin-yang balancing, Jim also had a growing interest in and endorsement for another key notion in the Chinese traditional philosophy, which was the notion of 'wu' (悟 in Chinese) in terms of intuitive imagination for insight via metaphor.

During my stay in Stanford as a visiting scholar in 2013, when we needed to think and debate over some critical issues, Jim often half-jokingly uttered the phrase of 'let's "wu"'. 'Wu' refers to the cognitive thinking in terms of intuitive imagination for insight via metaphor (in contrast the Western notion of intuition as 'gut feeling', especially the deep notion of sudden insight as the core result of 'wu' process). In particular, 'wu' was inherently related to Jim's strong interest in the notions of ambiguity, foolishness, and playfulness.

During my discussion with Jim over the past eight years, I could see clearly that Jim had placed high hope and also a high expectation on the success and impact of Chinese indigenous research. Jim once told me that the converging trend in US business schools toward a homogenous body of knowledge was unhealthy for management research in general; he once hoped that the European business schools could serve as the counter-balance to the US dominance, but he was disappointed that the overall trend among the European business schools was just following the US model; hence, he hoped that Chinese business schools would offer a necessary diversity.

These ideas were explicitly expressed in Jim's MOR 2005 article. Unfortunately, this seminal article had not received the due attention from scholars around the world, including Chinese scholars. I sincerely call for much greater attention to this great work!

It was a great pity that Jim never visited China. I once asked him where he would want to visit if he ever traveled to China. He said seriously that he wanted to travel along the traditional Silk Road. He wanted to see what it was like along the traditional Silk Road, and he asked me if I could find any video for him to watch. However, I had only the DVD in Chinese, and finally I found one from an online website; a video in Japanese with English subtitles. He was very happy when he received the video and told me that he would watch it as soon as possible.

In my in-depth interview with Jim in 2016, he discussed in more detail about the necessity of engaging in indigenous research. On one hand, he argued that the prevailing ideology of research was in explicit favor of generalizable theories to be shared among different local communities around the world. On the other hand, he cautioned that the risk was that the trend of global convergence was too far and too fast; we needed to maintain some diversity. Hence, the deep-rooted challenge was how to keep the converging trend from moving too far and too fast by deliberately sheltering the diversity among national or local sub-communities. For local 
sub-communities, they would lose their identities if they merged with the global community, and there was an inherent benefit in keeping the diversity among various local sub-communities. In particular, when there was a strong trend toward the global convergence, it is more necessary to have the counterbalance from the diverse local sub-communities. In short, the need for a balance between converging unity and diverging diversity is similar to the required balance between exploration and exploitation. Jim sometimes used the example of US immigration, especially in California, as a metaphor for the required balance between unity and diversity.

In particular, applying the framework of exploration-exploitation balance, Jim had a series of insights into how we should engage in indigenous research. He specifically stated that both the Chinese scholarly community and the international scholarly community would be better off if most Chinese scholars sought to be internationally recognized scholars, but at least some Chinese scholars must focus on distinctive Chinese features. In other words, most Chinese scholars can seek international reputation, but some should take a different path. For those who are bold enough to take an unconventional path, they must prepare for the challenges of being at major disadvantages in terms of fewer publications in English journals, less likely to get both tenure and promotion, and lower recognition in professional circles. In other words, engaging in indigenous research in China and anywhere else is similar to taking the road less travelled, rather than the road more popular (Cheng, Wang, \& Huang, 2009). This reminds me of Don Quixote in terms of having the strongest commitment to, and passion for, one's unique mission, vision, and values despite the major barriers and huge challenges.

Further, Jim argued that Chinese indigenous research would probably be best conducted by Chinese scholars (even mostly in Chinese language), even though such research was unlikely to become the mainstream in the global community. However, such indigenous research should be open to international interaction, while maintaining the indigenous identity. In that sense, Jim often referred to the Scandinavian community as a good role model, which had tried hard to be both international and local, and it had been successful in both areas.

The above issue of balancing global unity and local diversity is highly related to the Chinese indigenous frame of yin-yang balancing. In my interview in 2016, Jim told me that Western society was not familiar and comfortable with yin-yang thinking, and he believed that such a perspective was very fruitful for thinking about management and organization. In particular, Jim thought that the very notion of healthy tension was highly useful, especially as closely related to the exploration-exploitation link.

I assume that Jim saw the Chinese cultural tradition as more open to the notion of ambiguity, which refers to the co-existence of multiple distinctive perspectives for the same phenomenon or issue (March, 1994), so he organized two mini-conferences on the topic of ambiguity in decision-making in Chinese organizations in 2011 and 2012 (I joined both meetings). 
Related to the two mini-conferences, Jim proposed a special issue on the notion of ambiguity in the journal of Management and Organization Review with the theme of 'ambiguity and decision making in Chinese organizations and thought'. In the call for papers for the special issue, it is stated that 'readings both of contemporary reports on Chinese organizations and of traditional Chinese philosophy and literature suggest that Chinese traditions and practices may confront ambiguity with a frame that is different from the frame of Western rationality' (Augier, March, Rhee, \& Zhou, 2012: 485). Unfortunately, due to various reasons, the special issue did not get enough articles accepted and was never formally published.

It is interesting that one of Jim's former students, Mooweon Rhee, also shares the view that Jim was not only interested in, but also highly consistent with, Chinese traditional thinking (Rhee, 2012). Further, despite my strong desire to do joint research with Jim, he told me he would not collaborate with anyone who had not had dinner with him. It was unfortunate that I had never had dinner with Jim, even though we had lunch together on many occasions. It seems that the notion of guanxi was meaningful for Jim.

Over the years of exchanging ideas with Jim since 2010, and also based upon my further reading about Jim, I have a growing sense that Jim could be best characterized as an academic Don Quixote. In particular, Jim suggested that the idea of foolishness was necessary for exploration and radical innovation. This was because one must escape from the established ways of thinking in terms of thinking outside of the box.

Like the figure of Don Quixote, Jim took the similarly unconventional or nonmainstream path in his life-long career. In general, people like Don Quixote will choose a unique path no matter how challenging and difficult to take such a less travelled path as compared to the conventional or popular path. This commitment derives from Don Quixote's chosen identification as his or her destiny.

Jim told me during my 2016 interview, it was necessary to venture off the track for exploration, but it was also necessary to ultimately come back to the track for exploitation so as to complete the journey of one's life as well as one's career. I will never forget his wise advice, and I will always remember him as my informal mentor as well as a great yet unique scholar.

\author{
Peter Ping Li \\ University of Nottingham Ningbo, China \\ Center for Creative Leadership, USA \\ Copenhagen Business School, Denmark
}

\title{
REFERENCES
}

Augier, M., March, J. G., Rhee, M., \& Zhou, X. 2012. Call for Special Issue on 'Ambiguity and decision making in Chinese organizations and thought'. Management and Organization Revieze, 8(2): 485-486. 
Cheng, B., Wang, A., \& Huang, M. 2009. The road more popular versus the road less travelled: An 'insider's' perspective of advancing Chinese management research. Management and Organization Revieze, 5(1): 91-105.

Levinthal, D. A., \& March, J. G. 1993. The myopia of learning. Strategic Management Journal, 14(Winter): 95-112.

March, J. G. 1982. The technology of foolishness. In J. G. March, \& J. P. Olsen (Eds.), Ambiguity and choice in organizations: 69-81). Bergen, Norway: Universitetsforlaget.

March, J. G. 1991. Exploration and exploitation in organizational learning. Organization Science, 2(1): 71-87.

March, J. G. 1994. A primer on decision making: How decisions happen. New York: Free Press.

March,J. G. 2005. Parochialism in the evolution of a research community: The case of organization studies. Management and Organization Revieze, 1(1): 5-22.

March, J. G. 2010. The ambiguities of experience. Ithaca, NY: Cornell University Press.

Rhee, M. 2010. The pursuit of shared wisdom in class: When classical Chinese thinkers meet James March. Academy of Management Learning \& Education, 9(2): 258-279. 